\title{
Os refugiados do Estado Islâmico e a (des)construção da concepção de nacionalidade para concretização da justiça e da dignidade da pessoa humana
}

\author{
Jessica Fonseca Teles \\ Graduada em Direito, com período de intercâmbio na Universidade de Passau, na \\ Alemanha, e Mestre em Direito Público, com dissertação intitulada "Choque de \\ civilizações: a proibição do uso do véu islâmico no ocidente sob as perspectivas da \\ laicidade, do feminismo e da segurança", pela Universidade Federal da Bahia. Pós- \\ graduada em Direito Público pela Faculdade Baiana de Direito. E-mail: \\ jessicafteles@gmail.com
}

\section{Ricardo Maurício Freire Soares}

Pós-Doutor em Direito pela Università degli Studi di Roma La Sapienza, pela Università degli Studi di Roma Tor Vergata e pela Università del Salento. Doutor em Direito pela Università del Salento. Doutor em Direito Público e Mestre em Direito Privado pela Universidade Federal da Bahia. Professor dos Cursos de Graduação e Pós-Graduação em Direito da Universidade Federal da Bahia (Especialização/Mestrado/Doutorado). Professor da Faculdade Baiana de Direito e da Faculdade Ruy Barbosa. Professor em diversas Instituições., tais como: Università degli Studi di Roma La Sapienza, Università degli Studi di Roma Tor Vergata, Università degli Studi di Roma Tre, Università degli Studi di Milano, Università di Genova, Università di Pisa, Università del Salento, Universidade Autônoma de Lisboa, Universidade do Algarve, Universidad de Burgos, Universidad de Salamanca e Martin-Luther-Universitat. Professor do Complexo Renato Saraiva, do Curso Brasil Jurídico, do Curso Damásio Educacional, da Escola Judicial do Tribunal Regional do Trabalho, da Escola de Magistrados da Bahia e da Fundação Faculdade de Direito. Pesquisador e Líder de Grupo de Pesquisa vinculado ao CNPQ. Diretor e Membro do Instituto dos Advogados da Bahia. Membro do Instituto dos Advogados Brasileiros e do Instituto Geográfico e Histórico da Bahia. Palestrante e Autor de diversas obras jurídicas. Site Pessoal: www.professorricardomauricio.com. E-mail: ric.mauricio@ig.com.br

\section{Resumo}

Este artigo parte do contexto em que o Estado Islâmico avança sobre o Oriente Médio e norte da África, forçando seus cidadãos a se refugiarem em vários países, sobretudo na Europa. Destarte, a partir do crescente número de pedidos de refúgio, nem sempre bem recepcionados pela população e respectivos governos, procura-se explanar a necessidade 
desses países acolhedores de compreenderem sua responsabilidade moral e humanitária quanto a esses indivíduos, que têm direito de não sofrerem uma aculturação na nova sociedade e serem entendidos como pessoas humanas com dignidade. Para tanto, e sabendo-se que não devem ser repetidas as medidas injustas aos refugiados, como vistas no contexto do início do Século $X X$, sugere-se a desconstrução da concepção de nacionalidade, em especial na Europa, visto este conceito, na sua formulação clássica moderna de defesa da soberania e fronteiras, com fundamento numa base imutável de valores sociais, interfere negativamente na aceitação do outro.

\title{
Palavras-chave
}

Refugiados; Nacionalidade; Justiça; Dignidade; Desconstrução.

\section{Islamic State refugees and the descontruction of the conception of nacionality to enforce justice and dignity}

\begin{abstract}
This study concerns the current context in which the Islamic State progress in its comination over the Middle East and North Africa, forcing its citizens to take refuge in several countries, mainly in Europe. Thus, from the soaring number of applications for the refugee status, not always welcomed by the population or goverments, its attempted to explain these countries necessity to understand their moral and humanitary liability to the refugees, which have the right not to suffer a aculturation in the new society, as well to be understood as human people with dignity. Therefore, knowing that it is not to repeat the unfair measures against refugees, as seen in the early twentieth century, it is presented a deconstruction of the conception of nacionality, especially in Europe, in its modern classical formulation about sovereignty and borders, founded over a immutable base of social values, that interfere negatively in the other's acceptance.
\end{abstract}

\section{Keywords}

Refugees; Nationality; Justice; Dignity; Deconstruction.

\section{Sumário}

Introdução. 1. Breve incursão histórica: os refugiados do início do século XX. 2. O argumento desconstrutivista e a realização da justiça. 3. Sujeitos de justiça, responsabilidade sem limites e a linguagem do outro. 4. A proposta de delimitação cultural do significado ético-jurídico da dignidade da pessoa humana. 5. A dignidade da pessoa humana como valor-fonte da experiência axiológica do direito. 6 . 0 reconhecimento jurídico do princípio da dignidade da pessoa humana: da internacionalização dos direitos humanos ao fenômeno da positivação constitucional. 7. Uma nova concepção de nacionalidade em sociedades pluralistas. 7.1 A nacionalidade no 
contexto de uma ordem internacional. 7.2 As impregnações éticas em sociedades pluralistas e a defesa da cultura. Conclusões. Referências.

\section{Introdução}

Um ditado popularmente conhecido diz que "uma imagem vale mais que mil palavras". Pois em setembro de 2015, a imagem do menino sírio de três anos (FOTO..., 2015), Aylan Kurdi, morto nas areias de uma praia da Turquia, conseguiu atrair as atenções de todo o mundo de forma mais impactante para algo que já vinha ocorrendo há mais tempo, que era a fuga os sírios e pessoas de outras nacionalidades em decorrência ao avanço do Estado Islâmico sobre o Oriente Médio e o norte da África. No ano seguinte, outra imagem, dessa vez do menino Omran Daqneesh, encoberto de poeira e machucado, após bombardeio em Aleppo, na Síria, chocou o mundo com a realidade dos conflitos dessa região, que forçam a retirada de seus habitantes (MENINO..., 2016).

Algumas outras imagens dos refugiados, muitos dos quais sírios, chamaram a atenção em decorrência da quantidade de pessoas que caminham juntas em busca de um novo lugar para se estabelecerem e, enquanto isso não ocorre, concentram-se em campos de refugiados. Uma delas mostrou cerca de 2.000 sírios marchando pela Eslovenia em direção à Áustria (LA MARCHA..., 2015), rodeados de militares, para que se evitasse que alguns ficassem pela região, lembrando inevitavelmente as forçadas marchas dos judeus, em direção a campos de concentração, na época da Segunda Guerra Mundial.

O fluxo migratório causou divergências na União Europeia. Enquanto alguns países, como a Alemanha, anunciou a liberação orçamentária para receber refugiados e diz, com isso, esperar mudanças positivas (MERKEL..., 2015), outros, como a Hungria, apresentaram uma maior preocupação com a obrigação de receber aquelas pessoas. Inclusive, no caso desse outro país, foi construído um muro na fronteira com a Sérvia, para tentar diminuir o fluxo de entrada dos imigrantes (REFUGIADOS..., 2015). Na verdade, os governos temem que essa onda migratória possa trazer problemas sociais e econômicos, tendo em vista que muitos europeus estão desempregados e, assim, surge o medo da concorrência com os trabalhadores estrangeiros (O QUE..., 2015).

Diante desse quadro, partidos de direita começaram a ganhar mais força na Europa, como o Alternative für Deutschland (Alternativa para a Alemanha), de oposição ao governo de Merkel, e as figuras de Marine Le Pen e Geert Wilders, como candidatos à Presidente da França e de Primeiro Ministro da Holanda, que apresentavam, sobretudo, propostas anti-imigratórias. Mesmo tendo esses dois candidatos sucumbido às eleições gerais em seus países, em 2017, foi visível a ascensão do conservadorismo na Europa. 
No Reino Unido, o referendo popular que levou à decisão da saída deste Estado da União Europeia, o Brexit, bem como relatório publicado pela Câmara dos Comuns sobre a crise migratória (REINO UNIDO, 2016), a partir de estatísticas oficiais, confirmaram, em meados de 2016, a existência de preocupações da população e de políticos atinentes ao controle de suas fronteiras. Neste relatório, expôs-se com relação aos refugiados que arriscam suas vidas atravessando mares, que apesar dos esforços já terem salvo vidas, eles não conseguiam impedir, inclusive, as rotas de tráfico e entrada ilegal de pessoas, exigindo respostas rápidas da União Europeia, de forma a impedir, em primeiro lugar, que essas pessoas saíssem de seus países (REINO UNIDO, 2016, p. 27). Desconsiderado, assim, que muitas pessoas só têm a opção de sair de suas terras, por conflitos aos quais não deram causa e são maiores que suas forças, o Reino Unido adiantou-se em retirar-se do bloco para limitar sua responsabilidade e, consequentemente, evitar a necessidade de promover uma integração.

A crise migratória traz, inquestionavelmente, um problema de ordem orçamentária, a qual levou à proposta da Comissão Europeia, ainda em 2015, de promover a relocação de cerca de 160 mil dos indivíduos que chegavam principalmente à Grécia, Itália e Hungria para os demais Estados membros, nos próximos dois anos e, para essa medida, seriam disponibilizados 640 milhões de euros (REINO UNIDO, 2016, p. 31). A chanceler alemã, Angela Merkel, nesse mesmo sentido, já havia apelado por um esforço em comum dos demais membros da União Europeia, visto que não podiam apenas alguns poucos países receber tantas pessoas, bem como não era possível dizer que nada se tem a ver com a presente situação (O QUE..., 2015).

Contudo, ainda que seja efetivada a relocação de refugiados, estes enfrentam mais um problema, objeto deste artigo, que diz respeito à integração cultural e, consequentemente, defesa da própria dignidade desses indivíduos, visto que não conseguem, muitas vezes, aderir à realidade desses países, em razão de encontrarem uma cultura e hábitos distintos aos seus e pautados em valores cerrados de uma nacionalidade há anos enraizada. Por isso, objetivando demonstrar que há um risco de que, apesar de esforços orçamentários e relocação proposta, um completo acolhimento dos refugiados resta prejudicado se não se reconhece essas pessoas como pertencentes a uma nova sociedade, parte-se da teoria de Jack M. Balkin, o qual faz uma releitura da teoria desconstrutivista de Jacques Derrida, para formular o desconstrutivismo transcendental da concepção de nacionalidade, e, assim, alcançar uma justiça transcendente.

Antes, faz-se uma breve incursão histórica ao início do século $X X$, com base nas explanações de Hannah Arendt, para se analisar o risco que existe, diante de fortes fluxos 
migratórios, de serem manipulados instrumentos normativos com base nos próprios valores de uma dada sociedade, em defesa da nacionalidade. Analisam-se, posteriormente, alguns requisitos a serem observados, para que se chegue a conclusões justas quanto ao acolhimento desses refugiados, que pressupõe um compromisso de integração, para que não se tornem indivíduos que não podem voltar para seus países de origem, nem obtêm reconhecimento onde estão. Dentre estes requisitos, estão a consideração dessas pessoas enquanto sujeitos de justiça, a noção de uma responsabilidade dos países acolhedores sem contornos definidos a priori, bem como o esforço para a compreensão da linguagem "do outro".

Por fim, após a explanação da dignidade da pessoa humana enquanto valor-fonte de cada sociedade, mutável e dependente dos influxos que nela ocorrem, discorre-se, a partir das observações de Jürgen Habermas, sobre a possibilidade daqueles indivíduos que chegam a um novo país de lutarem pelo reconhecimento de sua cultura, sem correr os riscos de sofrer uma aculturação, permitindo-se, noutro giro, uma nova revisão da base valorativa sobre a qual se funda aquela sociedade, somente através da qual se pode concretizar a inclusão dos refugiados e, consequentemente, garantir a estes uma vida digna.

\section{Breve incursão histórica: os refugiados do início do século XX}

A onda migratória dos cidadãos de países afetados pelo bárbaro domínio do Estado Islâmico já é um dos eventos mais preocupantes deste século, não se tratando, no entanto, da primeira vez que se vê na história uma quantidade tão grande de pessoas sendo forçadas a sair de seus países e procurar asilo em algum outro. Dentre as desastrosas consequências da Primeira Guerra Mundial, viu-se uma intensa fragmentação geopolítica e uma reorganização de fronteiras nacionais, sobretudo na Europa, no meio da qual estavam sujeitos apátridas ou sem gozarem ao menos de um status seguro de nacionalidade.

Esse contexto é bem explanado por Hannah Arendt, ao tratar sobre o declínio do Estado enquanto nação e as consequências para os direitos humanos (2012, p. 369). Conta a filósofa alemã o quão difícil é descrever exatamente o que aconteceu na Europa, diante dos acontecimentos de 4 de agosto de 1914, que deflagraram a Primeira Guerra Mundial. As guerras civis e os conflitos políticos que sobrevieram culminaram em migrações de grupos que não conseguiam ser assimilados em nenhum lugar para onde 
iam. Esses indivíduos perdiam o seu próprio significado social, de forma que, no seu próprio país, não tinham mais um lar onde pudessem viver em paz, e quando saíam de lá, tornavam-se apátridas, sem ninguém que os recebesse. Sem esse significado social, fortemente atrelado à nacionalidade, acabavam por perder seus direitos humanos e, assim, perdiam todos os direitos, condenados a uma condição de verdadeira indignidade.

Com a remarcação das fronteiras e destituição de impérios, mormente o austrohúngaro, pessoas que se tornaram apátridas foram submetidas aos Tratados das Minorias, os quais, contudo, não eram reconhecidos como leis, de forma que aqueles indivíduos passaram a viver em situações de completa ausência de lei, sem contar com um governo central que os representasse ou defendesse. O fato é que ainda nesse período o vínculo a uma nação era imperiosa para que se pudesse usufruir dos mais diversos direitos.

Hannah Arendt tece, portanto, críticas aos Tratados, os quais significavam, na realidade, de um "idealismo fútil" ou mesmo "de tonta e leviana hipocrisia". Ademais, discorre Arendt que tais instrumentos normativos se limitavam a tutelar nacionalidades que apresentavam maioria considerável em ao menos dois Estados sucessórios, deixando de lado todas as demais nacionalidades, as quais se quedaram às margens do direito e sem governo, muitas vezes concentrados num mesmo país, de forma que, em alguns desses países, os povos nacionalmente frustrados e abandonados à sorte constituíam $50 \%$ de toda a população (ARENDT, 2012, p. 375).

A verdade é que os Tratados das Minorias deixava claro que apenas os "nacionais" poderiam ser cidadãos, e, por isso, aqueles de outras nacionalidades precisariam de alguma lei de exceção, a não ser que retornassem ao seu país de origem - o que representava um risco, diante da reformulação de fronteiras e da ascensão de novos governos ao poder - ou dela se rompessem completamente (ARENDT, 2012, p. 379).

As nações, no entanto, conta Arendt, chegaram à conclusão de que era impossível uma completa naturalização das minorias e refugiados, pelas dificuldades de aceitação cultural, num contexto em que as escolhas e opções nacionais estavam bem delimitadas, bem como era impossível uma repatriação, uma vez que os países de origem não aceitavam aqueles indivíduos de volta, por questões políticas e pela própria novidade que era as novas estruturas geopolíticas. Essa situação de não poder realmente ficar nem poder voltar à origem se agravava quando o apátrida, que "era uma 'anomalia para qual não existia posição apropriada na estrutura da lei geral', ficava completamente à mercê da polícia, que, por sua vez, não hesitava muito em cometer atos ilegais para diminuir a carga de indésirables no país" (ARENDT, 2012, p. 387).

Quanto mais os Estados, naquela época, equipavam sua estrutura policial, para 
controlar as massas de indivíduos refugiados e minorias que iam chegando, maior o perigo da transformação de um Estado de lei em Estado policial (ARENDT, 2012, p. 391). Assim, restou claro para a filósofa que os tratados voltados a esses indivíduos não se tratavam de uma proteção, mas puderam servir, inclusive, como instrumento para uma futura e conveniente expulsão coletiva.

Essa condição de "estado de exceção" foi capaz de suprimir os direitos tanto dos refugiados, quanto das minorias e apátridas, os quais se encontravam agora num vazio legislativo ou num âmbito de normas meramente formais, que, na prática, em nada alteravam sua situação. Os perigos desse contexto se tornam maiores diante de situações inesperadas, como uma guerra, em que rápidas e estratégicas decisões devem ser tomadas.

É o caso, como denuncia Giorgio Aganbem, do momento posterior aos ataques de 11 de setembro, em que, sob o pretexto de se defender a segurança nacional, o então determinado pelo presidente George W. Bush Patriot Act permitia manter preso por sete dias todo estrangeiro suspeito de atos que atentassem contra a segurança norteamericana, não determinando, no entanto, qual o status que o sujeito teria nessa situação e, assim, ficando acobertados os seus (eventuais) direitos (AGANBEM, 2004, p. 14).

Assim, o filósofo italiano ressalta que com a queda das democracias europeias entre as décadas de 30 e 40 do século XX, os poderes do Executivo foram enaltecidos, ao ponto de chegarem aos "plenos poderes", tornando possível que as decisões fossem estritamente políticas, consoante à conveniência, de modo a permitir a rejeição de quaisquer e eventuais direitos das minorias. A Primeira Guerra Mundial e os anos seguintes teriam servido como um verdadeiro "laboratório em que se experimentaram e se aperfeiçoaram os mecanismos e dispositivos funcionais do estado de exceção como paradigma de governo", inclusive a ampla identidade entre os Poderes legislativo e executivo, a qual apresenta uma tendência a se tornar uma "prática duradoura de governo" (AGANBEM, 2004, p. 19).

Diante desse quadro, Arendt conclui que foi neste período que os direitos humanos foram aniquilados, criticando, em especial, a referência das declarações apenas a um ser humano "abstrato", sem que guardasse qualquer contexto com uma determinada cultura ou sociedade. Isso porque, estando num país, não sendo, no entanto, reconhecido como um de seus iguais, aqueles que tinham deixado suas terras não obtinham direitos típicos de cidadão, e, consequentemente, não eram considerados detentores de direitos "humanos" ainda que tivessem de, cotidianamente, levar ali suas vidas.

Ser estritamente vinculado a uma determinada nacionalidade era, assim, um

Revista Publicum

Rio de Janeiro, v. 3, n. 1, 2017, p. 273-306.

http://www.e-publicacoes.uerj.br/index.php/publicum

DOI: 10.12957/publicum.2017.28999 
pressuposto para se usufruir direitos que as nações apresentavam como de todos, universais, mas que, na verdade, eram especificamente concretizados por cada Estado para apenas algumas pessoas (ARENDT, 2012, p. 399). A questão não era, então, a falta de igualdade entre os indivíduos, mas a inexistência de leis que se voltassem às minorias, permitindo-as as condições básicas para a sua própria dignidade. Infelizmente, a história mostrou um quadro em que minorias eram levadas a condições da selvageria, que ensejaram a Segunda Guerra Mundial.

\section{O argumento desconstrutivista e a realização da justiça}

Para se analisar a atual situação dos refugiados do Oriente Médio e do norte da África que procuram refúgio principalmente em países da Europa, essencial tecer considerações sobre a justiça. Em se tratando de uma crise, muitas são as dúvidas sobre como será o seu desenvolvimento e eventual desfecho. A verdade é que se deve esperar, em todo caso, que sejam tomadas medidas políticas, sociais e econômicas capazes de concretizar a justiça para todos os envolvidos da melhor e mais ampla forma possível, pois, por se tratar de um conceito transcendente, a justiça de uma dada medida somente é visualizada diante da análise concreta das circunstâncias envolvidas.

Uma concepção que considera distintos e importantes pontos que a justiça, enquanto valor, pode apresentar na sociedade é a desenvolvida por Jack M. Balkin, que propõe uma releitura da teoria de Jacques Derrida, ressaltando alguns pontos e remodelando outros, com o objetivo de utilizar o desconstrutivismo na crítica jurídica.

Para o desenvolvimento do seu trabalho, Balkin esclarece, inicialmente, que Derrida nunca tratou diretamente do tema da justiça, mas isso não impede que a sua teoria seja aplicada, muito menos considerando a própria desconstrução num viés transcendental. No entanto, o autor norte-americano se preocupa com a concretização do valor justiça, para a qual a desconstrução pode contribuir, ao tonar possível uma argumentação crítica das circunstâncias de cada caso, partindo-se dos conceitos envolvidos.

Nesse sentido, Balkin afirma que o objetivo da desconstrução transcendental não é a mera destruição de conceitos, mas, sim, uma retificação, baseadas na "fé nos valores humanos", que revela as identificações errôneas do que seja justo para corrigi-las, e consequente, reorganizar as hierarquias postas (BALKIN, 1994, p. 14). Assim, mostra-se maduro o suficiente para reconhecer que nem todo e qualquer caso será tomada uma decisão justa, mas igualmente confiante e otimista para continuar perseguindo a justiça, igualmente, em todo e qualquer caso. 
As ideias de Balkin encontram muitos pontos de identidade com a teoria de justiça proposta por Amartya Sen. Ele também apresenta a importância de conceitos transcendentais, mas reconhece também a importância de se procurar promover a justiça em cada caso, de forma que não se fique apenas limitado a valores abstratos, capazes de levar a uma ideologia cega ou mesmo um fundamentalismo, como explica. Sendo assim, aduz o autor, no mesmo sentido de Balkin, que a justiça nem sempre será obtida em todo e qualquer caso, restando muitos conflitos sem solução, mas isso não é razão suficiente para que se deixe de tentar obtê-la (SEN, 2011, p. 175). Ademais, afirma que as instituições criadas a partir de valores transcendentais servem como fundamentos, e é a partir delas que podem ser realizadas ações para concretizar a justiça, não se confundindo valores e "instituições que promovam a justiça" com a prática em si da justiça, o que seria, para ele, "uma espécie de visão institucionalmente fundamentalista" (SEN, 2011, p. 112).

Há objeções contra se levar valores abstratos em consideração, mas Balkin aponta que foi justamente de Platão que se originou um pensamento não-platônico sobre a ideia de justiça enquanto primário e indeterminado, como um mero esqueleto, que deve ser construído pela cultura (BALKIN, 1994, p. 11). Mas é inevitável que se parta de uma ideia transcendente de justiça, mesmo porque o homem não se limita a normas positivadas e convenções sociais, as quais, por sua vez, são salutares para a concretização da justiça e outros valores transcendentais, ainda que não o possa fazer de forma perfeita.

Uma dessas objeções é reconhecida pelo próprio Balkin, e, ironicamente, recai em um ponto que o autor acrescenta à teoria de Derrida, qual seja, a transcendentalidade da desconstrução, que vai para além de um contexto específico. Derrida parte propriamente de ideias de casos concretos, a Weltanschauung ou "visão de mundo" (DERRIDA, 2014, p. $235)^{1}$. Assim, quando se analisa a estrutura histórica, há casos - finitos - que permitem "dar conta de tudo", para compreender o mundo, exceto a abertura para a verdade, que é a filosofia, ponto exato em que uma concepção estruturalista fatalmente encontra seu limite (DERRIDA, 2014, p. 234).

Balkin, por sua vez, expande a teoria de Derrida, para conter nesse quadro uma ideia geral de justiça, capaz de abarcar o maior número de casos possíveis, tendo, por base, a transcendentalidade no próprio conceito de desconstrução. Com essa releitura, é enfatizada ainda mais uma desconfiança sobre normas e convenções culturais, tidas como pré-compreensões, retirando o foco que antes apenas recaía sobre os conceitos a serem

\footnotetext{
${ }^{1}$ A Weltanschauung é a doutrina filosófica na qual se baseava Edmund Husserl, também conhecida como "visão de mundo", trazendo pré-compreensões que auxiliam na compreensão de outros significados. 
desconstruídos e partindo-se para além do positivado, para expandir as fronteiras da visão desconstrutivista.

A desconstrução transcendental é, então, definida por Balkin como "o intervalo entre a capacidade humana de julgamento e avaliação que inevitável e necessariamente transcende as criações culturais e as determinações e avaliações da cultura que, por sua vez, articulam e exemplificam valores humanos" (BALKIN, 1994, p. 12). Isso significa que esse desconstrutivismo que ele propõe é um verdadeiro ato de pensar para de fora e para fora da cultura. E isso só se torna possível se se compreender que não há valores fixos, como escalas de medições pré-determinadas, mas, sim, uma capacidade de valorar, que jamais será totalmente determinada ou totalmente satisfeita, apesar de todo o esforço que possa ser empreendido (BALKIN, 1994, pp. 12-13).

O que dá forma à justiça, considerada, inicialmente, transcendental, é a cultura. Os valores transcendentais, no entanto, nunca são plenamente articulados nas convenções sociais, havendo uma constante diferença, um conceito-chave da teoria derridariana que Balkin utiliza para explicar a impossibilidade de uma definitiva e perfeita concretização da justiça.

Sobre a diferença, Derrida utiliza-se de um neologismo para falar em "diferência", para que assim, além da diferença no seu sentido denotativo, compreenda-se também no termo a ideia de "diferir no tempo", um "atraso". Haverá, portanto, sempre uma lacuna entre o que algo realmente é e o que se compreende que ele seja, porque no momento em que se tenta exprimir o significado de algo, este já perde a sua força originária, apresentando a impossibilidade de alguma vez ser no presente, fora do campo teorético (DERRIDA, 2014, p.18). Nesse mesmo sentido, explica o filósofo que é a estrutura que reduz essa força, e que "dizer a força como origem do fenômeno é sem dúvida nada dizer", uma vez que "quando ela é dita, a força é já fenômeno" (DERRIDA, 2014, p. 37). Foi essa compreensão que levou Balkin a entender os valores, inclusive a justiça, como primários (incohate) e impassíveis de plena satisfação (insatiable) (BALKIN, 1994, p. 12).

A partir desse entendimento, Balkin afirma que sempre haverá um abismo normativo, pois as instituições e normas criadas jamais são plenamente capazes de materializar por completo valores abertos, como a justiça. Disso se extrai que cada cultura desenvolve sua própria compreensão de justiça, levando em conta aqueles casos que são considerados mais relevantes. Assim, sempre existirão pontos que não serão analisados, uma vez que uma decisão deve ser tomada, dando um fim e limite a uma controvérsia, bem como é a escolha por tais pontos igualmente limitada a um contexto e referências (BALKIN, 1994, p. 38). 
Com afirma ainda o autor norte-americano, há uma incontornável situação contraditória em que, através de uma atividade que se pretende transcendental e que busca abarcar a todos, deve-se também considerar as particularidades de cada qual, em cada caso concreto (BALKIN, 1994, loc. cit). Nessa constante oscilação centrípeta e centrífuga, é impossível sejam consideradas todas as circunstâncias imagináveis para que sempre se alcance a justiça. No entanto, Balkin explica que a impossibilidade de se alcançar uma única e determinada resposta justa não implica na impossibilidade da desconstrução transcendental, mesmo que nunca se encontre um argumento completamente desconstrutivista (BALKIN, 1994, p. 60). A compreensão que se deve ter portanto, é que argumentos desconstrutivistas são sempre relativos, voltados a um caso específico e levando em apenas alguns pontos considerados relevantes, não existindo uma fórmula única para sua aplicação.

Conclui-se, então, que a desconstrução, como afirma Balkin, ajuda a reconhecer a discrepância entre os julgamentos categóricos e o contexto sobre o qual o julgamento observa (BALKIN, 1994, p. 53). A impossibilidade de concretizar uma justiça perfeita não deve, no entanto, impedir se se busque a justiça em diversos casos. Pelo contrário, a desconstrução preza por uma constante vigília de tudo o que se define enquanto justo, para que se possam fazer correções diante das mudanças de compreensão sobre um mesmo conceito ou caso concreto, de acordo com as circunstâncias. Nesse sentido, é uma crítica que está sempre não só desconstruindo, mas reconstruindo a própria humanidade.

\section{Sujeitos de justiça, responsabilidade sem limites e a}

\section{linguagem do outro}

Como mencionado na introdução, o intenso fluxo migratório de indivíduos do Oriente Médio e no norte da África traz à lembrança eventos passados, cuja repetição na história, certamente, não seria desejada, em especial com a positivação da dignidade da pessoa humana na Declaração Universal dos Direitos Humanos, de 1948. Certamente, a situação das minorias refugiadas e as guerras eclodidas foram alguns dos fatores que levaram à consideração desse valor a nível internacional, que já consta do preâmbulo como norteador das relações: "Considerando que o reconhecimento da dignidade inerente a todos os membros da família humana e de seus direitos iguais e inalienáveis é o fundamento da liberdade, da justiça e da paz no mundo [...]". 
Pelas considerações de Hannah Arendt, acima explanadas, uma simples ligação entre os indivíduos pelo conceito geral de "humanidade" e tratados formais foram insuficientes para resolver a questão dos refugiados da primeira guerra mundial, sendo necessária também uma consideração de suas particularidades culturais. Nesse novo século, com o avanço da dominação do Estado Islâmico, vários cidadãos podem se tornar apátridas, os quais buscarão sobreviver em outros países, com uma nova cidadania ou nacionalidade. A dúvida, que só deverá ser esclarecida pelos passos lentos da história, é como concretizar a inclusão dessas pessoas e, portanto, a própria justiça.

Um dos pontos tratados por Balkin para uma desconstrução transcendental e concretização da justiça é a identificação dos sujeitos de justiça, a qual guarda estreita relação com uma política para refugiados, a fim inclui-los na nova sociedade. $O$ autor aponta a existência de dois grupos, quais sejam, o daqueles considerados humanos e o dos considerados no mesmo nível dos animais. No entanto, afirma que a limitação entre esses dois grupos é instável, de forma que as fronteiras entre eles podem tanto implodir quanto expandir, de acordo com as circunstâncias (BALKIN, 1994, p. 18). Isso significa que um determinado indivíduo categorizado enquanto "animal", a exemplo de escravos das histórias coloniais de diversos países, pode passar para a categoria de "humano", a partir de novas concepções, bem como pode acontecer o contrário.

Mais profundamente, significa esse entendimento que refugiados do Estado Islâmico podem não vir a serem incluídos enquanto "humanos". Isso porque Balkin vislumbra a necessidade da realização de uma igualdade material, para além da formal, no momento em que "o Outro" deve ser compreendido em todas as suas diferenças e inferioridade (BALKIN, 1994, loc. cit.). Sem dúvidas, o acolhimento de sujeitos que vêm de culturas diferentes, apresentando, basicamente, língua, religião e tradições diferentes das que formam os países que os recebem já são desafios a mais para estes que buscam sobreviver aos conflitos que tomam suas casas.

A ideia de igualdade material é melhor traduzida quando Amartya Sen traz a necessidade de serem consideradas as capacidades de cada indivíduos. Neste ponto, Amartya Sen faz uma releitura sobre a teoria da justiça de John Rawls, aduzindo que a distribuição de bens primários é apenas um meio para outras coisas, inclusive a liberdade, mas que, para, além disso, deve ser considerada a vida humana, ou seja, as capacidades das pessoas para realizarem aquilo que realmente valoram e viverem bem, o que lhes dá ainda uma maior autonomia para uso de suas capacidades, conforme são oferecidas pela sociedade. Assim, explica o economista indiano que "a abordagem propõe um sério 
deslocamento desde a concentração nos meios de vida [mercadorias, bens de consumo] até as oportunidades reais [vida humana] de vida [...]" (SEN, 2011, pp. 267-268).

Nesse sentido, uma mera distribuição de bens é insuficiente, visto que alguns têm mais condições reais de utilizar e usufruir destes bens que outros, seja por razões individuais ou sociais (SEN, 2011, pp. 289-290)2. Assim, por exemplo, o acesso à educação a refugiados e imigrantes se torna muito mais complexo quando ainda existe uma barreira imposta pelo idioma ou mesmo por um eventual modelo de escola que seja distinto, sendo estes alguns dos fatores que deverão forçar os países que os recebem a realizar políticas próprias destinadas a uma inclusão também nesse sentido.

Além da consideração dos sujeitos de justiça, Balkin fala em responsabilidade sem limites, esclarecendo, inicialmente, o que entende por esse termo, extraído dos próprios escritos de Derrida. Afirma, assim, que o filósofo francês não haveria de utilizar a expressão enquanto uma responsabilidade infinita, porquanto essa compreensão feriria a própria ideia de justiça, visto que tornaria responsáveis pessoas que não deveriam sê-lo. Noutro sentido, entende, pois, pela ideia de uma responsabilidade indefinida (BALKIN, 1994, p. 26), sem contornos definidos a priori, considerando-se ainda que toda ação sempre terá diversos efeitos, alguns dos quais não poderão ser previstos ou calculados, aparecendo somente posteriormente, num outro contexto. Esse entendimento, aliás, coaduna-se com a interpretação de "diferença" e "diferência" que Derrida apresenta e que já foi acima explanada.

Ao se partir da compreensão de que os valores estão em constante desconstrução, numa eterna - apesar de impossível - busca pela sua perfeita concretização, modificamse, também, as responsabilidades a serem atribuídas em virtude da violação desses valores. Não de outra forma e a título de exemplo, a defesa do meio ambiente se tornou um valor nas sociedades atuais, surgindo novas compreensões sobre a natureza e expandindo o âmbito de responsabilização para aqueles que a destruírem ou não defendê-la. A verdade é que essa compreensão de responsabilidade como indefinida deixa clara que somente após o acontecimento do fato é que se pode compreender os valores envolvidos e o quão significativos são diante das circunstâncias, o que leva à conclusão de que a responsabilidade é sempre definida posteriormente. Por mais que se criem critérios, ainda que abstratos e gerais, num momento anterior, somente com a

2 São vários os fatores que influenciam nas capacidades humanas, segundo Amartya Sen. Dentre eles, podem ser citadas as heterogeneidades pessoais, as diversidades no ambiente físico, as variações no clima social e as diferenças de perspectivas relacionais. Nesse sentido, uma mera distribuição igualitária de bens é insuficiente, visto que cada indivíduo apresenta suas especificidades. 
compreensão do caso concreto é que se pode bem delinear as responsabilidades dos envolvidos.

É por essa razão que os países passam a reformar suas normas sobre imigração e asilo após a verificação da atual e intensa onda migratória (CÂMARA..., 2015; ALEMANHA..., 2015), com o fim de ajustar as responsabilidades que the são cobradas por todo o mundo com as circunstâncias apresentadas e as suas capacidades. A própria ONU, cobrou dos países que recebessem os refugiados, alegando que "a solidariedade não pode ser responsabilidade de apenas alguns poucos membros da União Europeia" (ONU..., 2015). Tendo em vista que uma igualdade não pode ser realizada apenas formalmente e que tratados passados, em especial os que foram feitos após Primeira Guerra Mundial, não são suficientes para garantir aos refugiados direitos para bem viver no novo país, espera-se que as novas leis tragam responsabilidades aos países que aceitam esses indivíduos, ao lado de políticas públicas inclusivas, ao invés de facilitarem barreiras para o seu recebimento e assimilação.

Obviamente que a concepção de responsabilidade deve também levar em conta uma ideia de proporcionalidade, levando-se em consideração o número de novos indivíduos em relação à quantidade de habitantes e mesmo o orçamento disponível que o país possa ter para recebê-los. Ademais, é também de se esperar que próprios refugiados tenham suas reponsabilidades nos seus novos países, uma vez que direitos sempre vêm acompanhados de responsabilidades e estas devem ser bem delineadas para que cada qual saiba o seu papel e os próprios limites da justiça sejam traçados.

Por fim, também para que a desconstrução contribua para a concretização da justiça, Balkin aponta a necessidade de se falar na linguagem do Outro. No entanto, tratase de uma ação que também não pode ser plenamente satisfeita, uma vez que não há como apreender todas as singularidades de uma pessoa, além do fato de traduções serem imperfeitas (BALKIN, 1994, p. 37). Na verdade, o mais próximo do ideal é que criar uma espécie de terceira linguagem que, apesar de ainda não ser a perfeita, é capaz de levar em conta pontos importantes dos discursos dos dois lados.

Falar na linguagem do outro trata-se de um comportamento que vai para além das fronteiras de um idioma e procura partir do ponto de vista daquele com quem se argumenta. Assim, Balkin afirma que é uma ação "sem limites", que só pode ser compreendida diante do caso concreto (BALKIN, 1994, p. 47). Ademais, a despeito de que sempre haverá a possibilidade de que as crenças de um serem mudadas pelo encontro com o Outro, não pode se tratar de uma "cooptação hermenêutica", a ponto de se submeter à argumentação do Outro, apenas por entendê-lo mais fraco ou vítima de uma 
dada relação (BALKIN, 1994, p. 46). O essencial é um equilíbrio e, ao lado da argumentação crítica, poder ser capaz também de reconhecer que uma das duas partes pode estar enganada em relação algo, sob dadas circunstâncias.

\section{A proposta de delimitação cultural do significado ético- jurídico da dignidade da pessoa humana}

Etimologicamente, o vocábulo "dignidade" está associado ao latim dignitas, o qual significa "valor intrínseco", "prestígio", "mérito" ou "nobreza". Disso extrai-se o entendimento de que o ser humano é um fim em si mesmo, dotado de uma qualidade que o é inerente e que o torna insuscetível de converter-se num meio ou instrumento para a realização de interesses econômicos, políticos e ideológicos nas mãos de outrem.

Para Ingo Sarlet (SARLET, 2001, p. 60), a dignidade da pessoa humana é a qualidade intrínseca e distintiva de cada ser humano, de forma que cada qual merece igualmente respeito, tanto pelas partes estatais, quanto pelos demais que compõem a sociedade. Implica, então, em falar num complexo de direitos e deveres fundamentais que assegurem a pessoa tanto contra um ato degradante e desumano, como garantam as condições existenciais mínimas para uma vida equilibrada e saudável, além de promover sua participação ativa e co-responsável nos destinos da própria existência em comunhão com os demais seres humanos.

Dessa forma, a dignidade da pessoa humana revela um núcleo de integridade, tanto física quanto moral, que deve ser garantido a todos os indivíduos por sua existência no mundo, relacionando-se com a realização espiritual e com as condições materiais de subsistência do ser humano, sendo vedada qualquer tentativa de degradação ou objetificação da pessoa em sociedade.

Ocorre que, como a condição ontológica do ser humano é de um ser mutável, dinâmico e submetido aos influxos histórico-sociais, o conceito de dignidade da pessoa humana não será propriamente lógico-jurídico, porquanto não pode ser definida em termos universais e absolutos. Por isso que a delimitação do significado ético-jurídico de que a pessoa é um fim em si mesmo deve ser buscada dentro de cada contexto histórico, econômico e cultural, num plano real de afirmação dos valores que integram a experiência concreta e permanentemente em construção dos direitos humanos fundamentais.

Nesse sentido, assinala Aquiles Guimarães (GUIMARÃES, 2007, p. 81) que a defesa da dignidade humana se baseia nos valores constitutivos da estrutura ontológica do 
indivíduo, enquanto ser localizado numa ambiência histórico-cultural a muda a todo instante. Por essa razão, a dignidade deve ser entendida como uma construção cultural, que espelha as exigências deontológicas fundamentais em prol do ser humano, variando no tempo e no espaço.

Decerto, a dignidade da pessoa humana significa um conjunto de valores da civilização incorporados ao patrimônio da humanidade, cujo conteúdo ético-jurídico vem associado a todo um plexo axiológico de direitos humanos fundamentais dos cidadãos, os quais vão sendo agregados historicamente como valores que materializam uma existência digna. Não é outro o entendimento de Fábio Comparato (COMPARATO, 2006, p. 481), para quem a dignidade da pessoa humana reúne em si a totalidade dos valores, sendo ela o supremo critério axiológico a orientar a vida humana. Decerto, os valores éticos não são visualizados pelo homem uma vez por todas e completamente, mas descobertos pouco a pouco, no curso da história. A pessoa é um modelo, ao mesmo tempo transcendente e imanente à vida humana, um modelo que se perfaz indefinidamente e se concretiza, sem cessar, no desenvolvimento das sucessivas etapas históricas.

O significado ético-jurídico da dignidade da pessoa humana compreende a totalidade do catálogo aberto de direitos humanos fundamentais, em sua permanente indivisibilidade e interação dialética, abarcando valores que se contradizem e preponderam a depender do momento histórico e das singularidades culturais de cada grupo social, tais como aqueles relacionados aos direitos de primeira dimensão/geração (vida, liberdade, igualdade, propriedade), segunda dimensão/geração (saúde, educação, assistência social, trabalho, moradia), terceira dimensão/geração (proteção ao meioambiente, preservação ao patrimônio artístico, histórico e cultural) e, até mesmo, de quarta dimensão/geração (paz, direitos de minorias, tutela em face da biotecnologia, proteção perante a globalização econômica).

Não é outro o entendimento de Marcelo Novelino (CAMARGO, 2007, p. 116), para quem é indiscutível a relação de dependência mútua entre a dignidade da pessoa humana e os direitos humanos fundamentais, pois ao mesmo tempo em que os direitos humanos fundamentais surgiram historicamente como uma exigência da dignidade de proporcionar um pleno desenvolvimento da pessoa humana, é certo também que somente através da existência dos direitos humanos fundamentais a dignidade poderá ser respeitada, protegida e promovida no cenário social.

Deste modo, o que se entende por dignidade da pessoa humana e, portanto, a sua própria delimitação conceitual, é resultado de uma construção cultural fluida e multiforme, a qual dá ensejo, em cada tempo e espaço, ao mosaico dos direitos humanos 
fundamentais de uma dada sociedade, para fins de uma convivência que melhor impede o aviltamento e a instrumentalização do ser humano.

\section{A dignidade da pessoa humana como valor-fonte da} experiência axiológica do direito

O equilíbrio entre indivíduos e a compreensão mútua, através de diálogos e da noção de responsabilidade que se guarda com os demais indivíduos na sociedade em que se vive, ambos fatores vistos como formas de se alcançar a melhor justiça, tal como representado em Jack Balkin, representam, consequentemente, uma verdadeira defesa da dignidade da pessoa humana. Esta, antes mesmo de seu reconhecimento jurídico nas Declarações Internacionais de Direito e nas Constituições de diversos países, figura como um valor, que brota da própria experiência axiológica de cada cultura humana, submetida aos influxos do tempo e do espaço. Daí porque, longe de ser enclausurada como um ideal absoluto e invariável, o princípio da dignidade da pessoa humana deve ser compreendida em sua dimensão histórico-cultural.

Decerto, a apreensão do sentido do princípio da dignidade da pessoa humana não se afigura como o produto metódico de procedimentos formais, dedutivos e indutivos, mas, em verdade, requer um conhecimento de base concreta e real, que repousa sobre valorações. Entendida a cultura como tudo aquilo que é construído pelo homem em razão de um sistema de valores, com o escopo de atender aos seus interesses e finalidades, será possível constatar que o princípio da dignidade da pessoa humana é dotado de um sentido de conteúdo valorativo, pertencente, portanto, ao campo da cultura humana.

Disso se apercebeu o tridimensionalismo jurídico, ao conceber o valor da dignidade como fundamento concreto do direito justo. Foi integrado nessa linha de pensamento que Miguel Reale (REALE, 1994, p. 74) desenvolveu a sua teoria tridimensional do Direito. Para ele, sendo a experiência jurídica uma das modalidades da experiência histórico-cultural, compreende-se que a implicação polar fato-valor se resolve, num processo normativo de natureza integrante, cada norma ou conjunto de normas representando, em dado momento histórico e em função de dadas circunstâncias, a compreensão operacional compatível com a incidência de certos valores sobre os fatos múltiplos que condicionam a formação dos modelos jurídicos e sua aplicação. 
Trata-se de um tridimensionalismo concreto, dinâmico e dialético, visto que estes elementos estão em permanente atração polar, já que o fato tende a realizar o valor, mediante a norma. A norma deve ser concebida como um modelo jurídico, de estrutura tridimensional, compreensiva ou concreta, em que fatos e valores segundo normas postas em virtude de um ato concomitante de escolha e de prescrição (ato decisório), emanado do legislador ou do juiz, ou resultante de opções costumeiras ou de estipulações fundadas na autonomia da vontade dos particulares.

Com essa teoria integrativa, Reale rejeita todas as concepções setorizadas de direito (normativismo abstrato, sociologismo jurídico e moralismo jurídico), postulando, assim, uma doutrina que requer a integração dos três elementos constitutivos do direito, numa unidade funcional e de processo, em correspondência com os problemas complementares da validade social (eficácia), da validade ética (fundamento) e da validade técnico-jurídica (vigência). O conhecimento jurídico desponta como uma ciência histórico-cultural e compreensivo-normativa, por ter por objeto a experiência social na medida em que esta normativamente se desenvolve em função de fatos e valores, para a realização ordenada da vida humana.

Segundo Reale (REALE, 1972, p. 275), o fundamento último que o Direito tem em comum com a Moral e com todas as ciências normativas deve ser procurado na dignidade intrínseca da própria vida humana, não como entidade abstrata à maneira dos jusnaturalistas, mas como ser racional destinado por natureza a viver em sociedade e a realizar seus fins superiores. Da análise da natureza racional do homem e da consideração de que o homem é por necessidade um animal político, resulta a ideia de que cada homem representa um valor e que a pessoa humana constitui o valor-fonte de todos os valores. A partir deste valor-fonte, torna-se possível alcançar o fundamento peculiar do Direito, remetendo ao valor-fim próprio do Direito que é a Justiça, entendida não como virtude, mas em sentido objetivo como justo, como uma ordem que a virtude justiça visa a realizar.

Neste sentido, o Direito se desenvolve porque os homens são desiguais e aspiram à igualdade, inclinando-se para a felicidade e querendo ser cada vez mais eles mesmos, ao mesmo tempo em que aspiram a uma certa tábua igual de valores. Refere o jurisfilósofo que a ideia de justiça, que, no seu sentido mais geral, exprime sempre proporção e igualdade, é própria da dignidade da pessoa humana, como ente racional e social. Vivendo em sociedade e procurando o seu bem, o homem acaba compreendendo a necessidade racional de respeitar em todo homem uma pessoa, condição essencial para que também possa se afirmar como pessoa. Sendo assim, a ideia de Justiça liga-se, de maneira imediata

Revista Publicum

Rio de Janeiro, v. 3, n. 1, 2017, p. 273-306.

http://www.e-publicacoes.uerj.br/index.php/publicum

DOI: 10.12957/publicum.2017.28999 
e necessária, à ideia de pessoa humana, pelo que o Direito, como a Moral, figura como uma ordem social de relações entre pessoas.

$\mathrm{Na}$ visão de Miguel Reale (REALE, 1972, p. 300), os valores que se ligam necessariamente ao valor-fonte da dignidade da pessoa humana constituem o conteúdo próprio da justiça e, uma vez traduzidos em preceitos incorporados à cultura, tornam-se eles preceitos universais, comuns a todos os povos e lugares, pelo que toda regra que atualize esses preceitos fundamentais conta com o assentimento dos sujeitos. Ao lado destes preceitos gerais que exprimem a constante ética do Direito, outros há que também servem de fundamento às regras do Direito Positivo, na condicionalidade de cada cultura, representando as infinitas formas de integração dos valores mais altos no desenvolvimento histórico das civilizações em face do lugar e do tempo.

Dentro da dimensão valorativa do direito e no campo da fundamentação de sua validade ética, o problema da justiça adquire relevo. O que importa não é a definição da justiça - dependente sempre da cosmovisão dominante em cada época histórica -, mas sim o seu processo experiencial através do tempo, visando a realizar cada vez mais o valor da dignidade da pessoa humana, valor fonte de todos os demais valores jurídicos.

Pode-se afirmar que, nesse contexto, a justiça se apresenta como condição transcendental da realização dos demais valores, por ser a base sem a qual os demais valores não poderiam se desenvolver de forma coordenada e harmônica, em uma comunidade de homens livres. É por tal razão que a justiça deve ser entendida como um valor franciscano, na condição de valor-meio, sempre a serviço dos demais valores para assegurar-lhes seu adimplemento, em razão da dignidade da pessoa humana que figura como o valor-fim da ordem jurídica.

\section{O reconhecimento jurídico do princípio da dignidade da pessoa humana: da internacionalização dos direitos humanos ao fenômeno da positivação constitucional}

Embora o respeito à dignidade da pessoa humana seja uma concepção que surge de matrizes culturais remotas, desde a antiguidade greco-latina e cristã, até o renascimento e o iluminismo antropocêntrico da idade moderna. No pensamento filosófico da antiguidade clássica, verifica-se que a dignidade da pessoa humana estava relacionada com a posição social ocupada pelo indivíduo e o seu grau de reconhecimento pelos 
demais membros da comunidade. Por outro lado, já no pensamento estóico, a dignidade era tida como a qualidade que, por ser inerente ao ser humano, o distinguia das demais criaturas, no sentido de que todos os seres humanos eram dotados da mesma dignidade.

Durante o período medieval, segundo a religião cristã, o ser humano foi criado à imagem e semelhança da Divindade, premissa da qual o cristianismo extraiu a consequência de que o ser humano é dotado de um valor próprio e que the é inerente, não podendo ser transformado em mero objeto ou instrumento. Destacou-se Tomás de Aquino, o qual chegou a referir expressamente o termo dignitas humana, ratificado, já em plena Renascença, pelo humanista italiano Pico Della Mirandola, que, partindo da racionalidade como qualidade peculiar inerente ao ser humano, postulou ser esta a qualidade que the possibilita construir de forma livre e independente sua própria existência e seu próprio destino.

No âmbito do pensamento jusnaturalista do século XVII e XVIII, a concepção da dignidade da pessoa humana, assim como a ideia do direito natural em si passou por um processo de racionalização e laicização, mantendo-se, todavia, a noção fundamental, da igualdade de todos os homens em dignidade e liberdade. Dessa concepção jusnaturalista decorreu a constatação de que uma ordem constitucional que consagra a ideia da dignidade da pessoa humana parte do pressuposto de que o homem, em virtude tão somente de sua condição humana e independentemente de qualquer outra circunstância, é titular de direitos que devem ser reconhecidos e respeitados por seus semelhantes e pelo Estado.

Após o refluxo da preocupação filosófica pela dignidade humana, por força do cientificismo positivista do século XIX, a retomada do debate acerca da dignidade da pessoa humana teve, como marco simbólico, a década de quarenta do século passado, após o término da Segunda Grande Guerra Mundial, cujas barbáries e atrocidades cometidas contra o ser humano demonstraram a incongruência da metafísica jusnaturalista e do alheamento ético do positivismo jurídico.

A pesar de instrumentos como a Magna Charta Libertatum de 1215, a Paz de Westfália de 1648, o Habeas Corpus Act de 1679, as declarações burguesas norteamericana e francesa, ou mesmo a instituição da Organização Internacional do Trabalho serem exemplos de alguns dos precursores na defesa dos direitos humanos, estes somente passaram a ser constantemente debatidos nos discursos internacionais a partir da criação das Nações Unidas, em 1945, cuja Carta constitutiva objetiva a cooperação internacional e persecução da paz e da segurança em conformidade com os princípios da justiça e do Direito Internacional. 
Como bem refere Peces-Barba Martinez (MARTINEZ, 2003, p. 11), a luta pela afirmação da dignidade da pessoa humana, em meados do século vinte, robustecida após a traumática experiência totalitária na Segunda Guerra Mundial, como fonte dos direitos fundamentais do cidadão, trata-se de uma resposta tanto ao movimento jusnaturalista, quanto às construções positivistas que debilitaram as referências morais do fenômeno jurídico, erigindo o respeito à condição do ser humano como valor supremo dos sistemas jurídicos de inspiração democrática.

Decerto, os grandes textos normativos desse período histórico passaram a reconhecer a ideia dignidade da pessoa humana, seja no âmbito do Direito Internacional, seja no plano específico do Direito Nacional de cada Estado soberano. Inicialmente, esse processo ocorreu com a internacionalização dos direitos humanos, que passaram a ser enunciados no âmbito da comunidade jurídica supranacional.

Nesse sentido, a Declaração Universal dos Direitos do Homem, aprovada pela Assembleia Geral da Organização das Nações Unidas em 1948, é inaugurada com a afirmação de que todos os seres humanos nascem livres e iguais, em dignidade e direitos (art. 1ํ), além de proclamar o caráter de igualdade fundamental dos direitos humanos, ao dispor que cada qual pode se prevalecer de todos os direitos e todas as liberdades proclamadas na presente Declaração, sem distinção de espécie alguma, notadamente de raça, de cor, de sexo, de língua, de religião, de opinião pública ou de qualquer outra opinião, de origem nacional ou social, de fortuna, de nascimento ou qualquer outra situação (art. 2ㅇ).

Como sustentam Dimitri Dimoulis e Leonardo Martins (DIMOULIS; MARTINS, 2007, p. 40), os direitos fundamentais no âmbito internacional recebem o nome de direitos humanos, indicando o conjunto de direitos e faculdades que garantem a dignidade da pessoa humana e se beneficiam de garantias internacionais institucionalizadas. Essa internacionalização vai além do relacionamento binário Estado-Indivíduo que é a concepção tradicional dos direitos fundamentais, trazendo uma nova concepção de tutela da dignidade do ser humano: ampliação dos titulares de direitos; possibilidade de responsabilizar o Estado de forma externa; politização da matéria devido à necessidade de se realizar contínuos compromissos entre os Estados e os atores internacionais.

A partir da internacionalização da dignidade da pessoa humana e dos direitos humanos correlatos, seguiu-se o fenômeno da constitucionalização desses direitos humanos, que passaram a ser denominados, com a positivação constitucional, de direitos fundamentais, ampliando a possibilidade de garantir a sua aplicabilidade nas relações sociais desenvolvidas no âmbito dos ordenamentos jurídicos internos. 
Ao tratar da exteriorização da dignidade da pessoa humana como princípio do constitucionalismo ocidental, observa J. J. Gomes Canotilho (CANOTILHO, 1998, p. 221) que o ser humano passou a despontar como o fundamento da República e limite maior ao exercício dos poderes inerentes à representação política. Perante as experiências históricas de aniquilação do ser humano (inquisição, escravatura, nazismo, stalinismo, polpotismo, genocídios étnicos) a dignidade da pessoa humana significa, sem transcendências ou metafísicas, o reconhecimento do homo noumenon, ou seja, do indivíduo como limite e fundamento do domínio político da República.

Exemplos não faltam desse processo de positivação constitucional da dignidade da pessoa humana. A Constituição da República Italiana, de 27 de dezembro de 1947, estatui que "todos os cidadãos têm a mesma dignidade social" (art. 3ㅇ). A Constituição da República Federal Alemã, de 1949, contempla solenemente, em seu art. 1ㅇ, que "a dignidade do homem é inviolável. Respeitá-la e protegê-la é dever de todos os Poderes do Estado". Analogamente, a Constituição Portuguesa de 1976 abre-se com a proclamação de que "Portugal é uma República soberana, baseada na dignidade da pessoa humana e na vontade popular e empenhada na construção de uma sociedade livre, justa e solidária". Outrossim, a Constituição Espanhola de 1978 declara que "a dignidade da pessoa, os direitos invioláveis que lhe são inerentes, o livre desenvolvimento da personalidade, o respeito à lei e aos direitos alheios são o fundamento da ordem política e da paz social" (art. 10).

Esse progressivo reconhecimento jurídico da dignidade da pessoa humana, como sustenta Robert Alexy (ALEXY, 2007, p. 10), representa a passagem dos direitos humanos, dotados de natureza suprapositiva e de universalidade moral, geralmente expressos em tratados em convenções internacionais, para os direitos fundamentais, que se apresentam como direitos que foram acolhidos numa Constituição. A positivação desses direitos do homem não anula a sua validez ética, reforçando, em verdade, a sua exigibilidade jurídica, diante de conflitos de interesse entre os atores sociais. Jürgen Habermas, a seu turno, não encontra na moral o fundamento único e direto do direito, o qual está, na verdade, no princípio do discurso, em que os possíveis atingidos das decisões políticas possam participar da democracia, tendo conhecimento das regras envolvidas. Entretanto, o filósofo alemão não nega a existência de um contato entre direito e moral, o que se dá justamente através da concepção de dignidade humana.

Habermas então afirma que, além de a dignidade humana ter estado sempre presente nas diversas lutas por direitos humanos, ainda que sob qualquer outro título, ela permite uma ordem política fundamentada em um direito legítimo, de acordo com as 
circunstâncias históricas que são dadas, sendo uma espécie de "dobradiça conceitual que conecta a moral do respeito igual por cada um com o direito positivo e com a legislação democrática" (HABERMAS, 2012, pp. 17-18).

Com efeito, a proclamação da normatividade do princípio da dignidade da pessoa humana, na grande maioria das Constituições contemporâneas, conduziu ao reconhecimento da eficácia jurídica dos direitos humanos, afastando-se a concepção anacrônica da sua inexigibilidade em face de comportamentos lesivos à vida digna, seja por ações de governantes ou de particulares, por se tratar de máximas ético-morais desprovidas de coerção e de imperatividade. Dentro dessa tendência, não se pode dispensar o tratamento digno e humanitário às pessoas que tem suas vidas deslocadas em razão de ataques de terroristas islâmicos, independentemente de suas vontades, existindo uma verdadeira responsabilidade moral, com eficácia jurídica internacional.

\section{Uma nova concepção de nacionalidade em sociedades}

\section{pluralistas}

Se Hannah Arendt afirmou que um dos fracassos da questão dos refugiados do século XX foi a impossibilidade destes terem uma nacionalidade definida, havendo hoje uma ordem jurídica internacional, o que torna a pessoa um sujeito de direitos e de justiça é a possibilidade de exercer sua cultura, independentemente e muito além da sua nacionalidade. O problema é entender como conviver com distintas práticas em um mesmo lugar, de forma que diferentes culturas sejam contempladas, diante da tendência de rejeitar o "estranho".

\subsection{A nacionalidade no contexto de uma ordem internacional}

Na história moderna, pode-se perceber o fortalecimento de sociedades globais em torno de Estados, os quais decorreram de longos processos iniciados no século XVI até sua consolidação, nos moldes tais como se conhece nos dias atuais, mesmo não se negando que desde a Antiguidade Clássica já houvesse sinais precursores dessa realidade (BASTOS, 1995, p. 6). Desde a origem do Estado, uma de suas principais características é a capacidade de definir a sua soberania, tanto externa quanto internamente, sendo capazes, portanto, de fortalecer as suas fronteiras para impedir as investidas de 
dominação externas, afirmando seu reconhecimento internacional, bem como de impor a sua ordem jurídica aos súditos do rei, além de se estruturar por meio do monopólio de poder e administração diferenciada, autônoma e financiada por impostos e com base em organizações executivas burocráticas (HABERMAS, 2004, p. 130).

Quanto ao termo "nação", Habermas explica que este era, originariamente, empregado ainda no período do feudalismo para se referir aos vínculos entre o rei e associações, as quais, em troca de tributos e proteção militar ao reino, obtinham uma parcela de poder político, sendo assim um braço direito do monarca. Somente depois foi que a expressão passou a abarcar outras camadas da sociedade, dotando-se de caráter popular, sobretudo com a participação dos burgueses que começavam que começavam a ascender ao poder com as revoluções do final do século XVIII, as quais acabariam por destituir as monarquias despóticas. Dentre eles, estavam presentes eruditos capazes de difundir a nova ideia de nacionalidade, a qual serviu para fechar as fronteiras dos Estados, agora qualificados como nacionais, em defesa contra os povos estrangeiros, estranhos que deveriam então ser hostilizados, em prol da soberania estatal externa (HABERMAS, 2004, p. 133).

O interesse de se enaltecer a nacionalidade é constatado nos Discursos à nação alemã, do filósofo Johann Gottlieb Fichte. Com esta obra do idealismo moderno alemão, pretendia-se a coesão e união do povo como forma de encarar o combate contra aqueles que eram diferentes e, portanto, não eram nacionais alemães. Ela voltava-se a uma educação de caráter militar e controlada pelo poder político central, cujo objetivo central era a conversão dos seus jovens em "cidadãos melhores", para que lutem pela independência supostamente perdida para a presença de correntes de pensamentos e indivíduos estrangeiros (FICHTE, 1943, pp. 186-187).

Semelhante tendência nesta época também estava presente no Contrato Social de Jean-Jacques Rousseau, o qual pugnava por uma civilidade, por entender que o povo era "disciplinável ao nascer", mas cabia igualmente a ele aguardar pelo "momento da maturidade", o qual teria sido perdido quando da invasão de estrangeiros, tais como os russos. Por essa razão, acreditava que os franceses jamais prosperariam (2004, p. 54). Textos assim direcionados aos povos, especialmente as juventudes em desenvolvimento, trazem uma identidade: enaltecer os seus próprios atributos e qualidades, além de diminuir as outras nações, entendidas como inimigas que deveriam ser combatidas.

Dentro das novas Repúblicas, originadas das revoluções burguesas, só a ideia de nação é que poderia tornar os cidadãos coesos, através de uma solidariedade a favor da pátria e da sua liberdade. Se antes a legitimação estatal se pautava na graça divina do 
monarca soberano, agora era a ideia de nação, como "uma pessoa privilegiadamente soberana", que unia os indivíduos que sustentava a importância do Estado (BONAVIDES, 2003, p. 131). O patriotismo observado, por exemplo, na Revolução Francesa, decorria da própria concepção de nacionalidade e, assim, de pertencimento a um grupo determinado, cujos integrantes detinham origens comuns, quer seja na língua, na cultura ou na história, unia os cidadãos para a defesa das fronteiras e impelia ao combate contra todos os estranhos e não-nacionais, ganhando forças, sobretudo, com a obrigatoriedade do serviço militar (HABERMAS, 2004, p. 137).

Habermas aponta que essa origem comum dos cidadãos era compreendida naturalisticamente, como existente em decorrência da condição natural do homem. Ela teve origem com o pensamento liberal próprio da época, baseado na premissa da igualdade formal de que todos eram iguais perante a lei. Entretanto, aduz o filósofo alemão que o nacionalismo serviu, na verdade, como meio de mobilização das massas a favor do imperialismo e dominações, especialmente na passagem do século XIX ao XX, o que permite entrever a possibilidade de se utilizar esse termo de forma abusiva por parte das elites detentoras do poder (HABERMAS, 2004, p. 139).

Os Estados nacionais formados por indivíduos de uma origem comum, caracterizadora da nação, que mantinha os indivíduos coesos contra investidas de nãonacionais, entretanto, não se sustentaria, dessa forma, por muito tempo. De fato, o processo de globalização que viria a se seguir, desencadeado a partir das revoluções industriais entre a passagem do século XVIII ao século XIX, viria a permitir um multiculturalismo que desestruturaria a homogeneização possibilitada pela formação de uma nação.

Diante desse quadro, as populações passam a não se apresentar mais de forma homogênea, como o mito do nacionalismo havia permitido com o fito de salvaguardar a própria soberania estatal. Habermas aponta, inclusive, que esse novo contexto não pode ser evitado, exceto no caso de se lançar mão, novamente, de barbáries que busquem uma limpeza étnica, como se viu com o terror da Segunda Guerra Mundial. Aliás, justamente após o seu término, afirma o filósofo que não havia mais razão para manter os indivíduos de uma sociedade coesos através de uma ideia de nacionalidade, visto que a sua valorização extremada somente propiciou a dominação de povos, destruição e um contínuo medo da beligerância que ainda apresentavam os Estados, notadamente com a Guerra Fria que se sucedeu (HABERMAS, 2004, p. 142).

Nesse ínterim, uma nova configuração de Estado traz consigo a revitalização dos cidadãos, que agora tinham acesso a reformas na educação, previdência, saúde etc. Os 
direitos de um Estado social passaram, assim, a ser a nova forma de integração dos indivíduos da sociedade, que antes se referia à nacionalidade, a qual não desapareceu, mas perdeu significativa importância. Os Estados passaram a concretizar dos direitos dos seus cidadãos, o que passou a uni-los, pois ter esses direitos concretizados os fazia acreditar naquele Estado. Nesse momento, percebeu-se também a importância do equilíbrio entre o poder privado e o estatal, bem como da constituição como meio de realizar esses direitos, sendo criados e ampliados sistemas de seguridade social, com reformas em áreas como educação, família, direito penal e poder carcerário, políticas feministas de igualização dentre outras (HABERMAS, 2004, p. 143). Passou-se a equacionar, assim, o jurídico e o factual, superando-se a mera visão de igualdade formal, antes cultuada pelo liberalismo, e partindo-se para a concretização da igualdade material.

Mas a mera distribuição de bens sociais, garantidas por leis e decretos, não é suficiente para se garantir uma ordem social pluralista de forma harmônica. Como já salientado, a partir das considerações de Jack Balkin e Amartya Sen, é preciso antes reconhecer todos os indivíduos como detentores de direitos, e, acima de tudo, como seres humanos dotados de dignidade inviolável, levando em conta as suas particularidades e capacidades. Somente assim podem, efetivamente, ser incluídos na sociedade em que vivem, com acesso aos mesmos direitos que todos os demais têm, inclusive nos processos de discussão e formação dos mesmos. E essa necessidade de inclusão e reconhecimento se torna tanto maior quanto mais intensos ficaram os processos de imigração, como se observou no contexto das Guerras Mundiais (HABERMAS, 2004, pp. 263-264) e também se observa no atual contexto dos refugiados na Europa.

Hoje é notório que as barreiras econômicas de diversos países estão flexíveis, diante da formação de blocos econômicos e grandes transnacionais. A evolução da concepção sobre direitos humanos, por sua vez, também busca acompanhar a tendência da economia e ultrapassar os limites dos ordenamentos jurídicos internos de cada Estado para criar uma ordem jurídica internacional, o que se pode visualizar, por exemplo, com a atuação das Nações Unidas e tribunais internacionais. Assim, a soberania estatal, antes blindada pela ideia de defesa da nação, que se constituía de um povo com uma origem comum, ganha novos contornos que se adéquam à nova realidade, pois a atuação jurídica de um Estado passa a ser observada por todos os demais, vinculados por tratados e acordos, em torno de instituições como a Organização das Nações Unidas.

É de se reconhecer, no entanto, as dificuldades de se criar instrumentos normativos internacionais que abarquem de forma considerável o maior número possível de interesses de distintas nações, como se vê com os recentes fracassos na tentativa de 
uma constituição europeia (HOLANDA..., 2005). Ademais, é notável que normas internacionais buscam determinar a proteção de valores de forma abstrata, no que tribunais internacionais acabam, muitas vezes, por se apresentarem favoráveis ao entendimento de que cada país tem a autonomia suficiente para decidir sobre um caso que Ihe seja particular, ainda que ocorra situação semelhante em outros países ${ }^{3}$. Isso porque, conforme o entendimento de Balkin já acima explanado, somente a cultura de um país é capaz de articular os valores construídos abstratamente por órgãos internacionais.

No entanto, o fato é que não só podem os países, exercendo sua soberania, delimitar as regras que deseja seguir, bem como há agora uma ordem jurídica internacional cada vez mais consolidada, apesar de todas as dificuldades, que traça os parâmetros gerais a serem seguidos, compreendidos como valores transcendentais mínimos a serem observados para uma vida digna e justa, modelados por cada Estado de acordo com suas particularidades. Destarte, ressalta Flávia Piovesan, como consequência de um mundo multicultural, em que as barreiras nacionais não mais se sustentam na exclusiva justificativa de uma nação homogênea e estabelecida com valores únicos, visualiza-se uma tendência de se levar questões anteriormente discutidas internamente a uma ordem internacional institucionalizada, que procura defender direitos dos homens, para se evitar que os Estados se omitam de dar o tratamento desejável aos seus cidadãos (PIOVESAN, 2013, p. 191).

Nesse sentido, Piovesan também destaca que houve uma remodulação tanto da soberania dos Estados, como também do próprio cidadão, definido agora dentro de um cenário internacional (PIOVESAN, 2013, p. 183) e, em especial, da nacionalidade, estando as fronteiras entre os países cada vez mais maleáveis e sendo, muitas vezes, quase imperceptível uma origem comum entre os habitantes de uma mesma região. Obviamente, como já foi dito, não houve uma destruição das barreiras nacionais, porém tornou-se mais consolidada a ideia de que todos são pessoas humanas dignas, antes de pertencerem a qualquer país e, consequente, estarem vinculados a uma gama de entendimentos e valores ali definidos.

\footnotetext{
${ }^{3}$ A título de exemplo e a respeito do direito à liberdade religiosa, presente na Declaração dos Direitos do Homem e do Cidadão e outros instrumentos internacionais, a Corte Europeia de Direitos Humanos, ao analisar dois casos semelhantes sobre proibição do uso do véu islâmico, um da França e outro da Turquia, apresentou o mesmo entendimento, no sentido de que se admite que as mulheres muçulmanas podem interpretar a restrição legal francesa/turca como "uma ameaça à sua identidade", mas que ao Estado cabe a função de "organizador neutro e imparcial do exercício de várias religiões", definindo, assim, que a restrição de tal direito é "uma escolha da sociedade". Cf. Case of S.A.S v. France (Application no. 43835/11) e Case of Leyla Şahín v. Turkey (Application no. 44774/98).
} 


\subsection{As impregnações éticas em sociedades pluralistas e a defesa da cultura}

Assim como se extrai do entendimento de Jack Balkin, Jürgen Habermas afirma que é a partir de valores universais que o legislador define as normas jurídicas específicas de uma determinada sociedade, levando-se em conta as características culturais que the são inerentes, não significando isso que o ordenamento jurídico seja formado unicamente por posicionamentos políticos e, portanto, subjetivos, pois "a consideração de fins coletivos não pode dissolver a estrutura do direito, não pode destruir a forma jurídica como tal, e com isso suprassumir a diferenciação entre direito e política" (HABERMAS, 2004, p. 253). No entanto, ele aponta a existência de impregnações éticas, ou seja, influências de alguns grupos, geralmente dominantes, dentro do processo de formação política dos Estados.

Um tema que ganha relevo ocorre justamente quando uma minoria surge no seio de uma sociedade já definida historicamente e passa a querer o seu próprio reconhecimento e a aquisição de direitos, assim como todos os outros daquele grupo, inclusive como uma forma de proteção contra a dominação. Isso se dá porque questões ético-políticas, inevitavelmente, farão parte da política, inclusive como formação da identidade da sociedade e dos seus cidadãos, o que pode dar ensejo a batalhas travadas por minorias que sejam eventualmente desprezadas.

Pablo Lucas Verdú, a partir das observações de David Philip sobre a sociedade sueca, também acredita ser a pluralidade uma importante característica das sociedades ocidentais modernas (VERDÚ, 2007, pp. 94-96). Explica que, dentro delas, há grupos intermediários que se comunicam, de forma que, indivíduos de camadas sociais distintas, acabam sempre se encontrando e estabelecendo compromissos entre si, o que facilita o reconhecimento uns dos outros. Na visão do autor, a democracia pluralista permite mais mobilidade nas relações dentro de grupos e entre eles, o que deve ser permitido, ao invés da pretensão liberal burguesa de impedir a fluidez de uma sociedade a partir de postulados rígidos e estáticos.

No mesmo sentido, Habermas entende que para se tutelar, concretamente, os direitos de uma pessoa, não se pode desconsiderar as relações intersubjetivas pelas quais ela formou a sua identidade e forma de viver. Outrossim, entende que o Direito se presta à tutela de indivíduos em si, mas não à tutela de grupos inteiros, pois deve-se ceder espaço para que o sujeito opte pela sua própria forma de vida e consagre, assim, a sua identidade. Reforça, por fim, o posicionamento da necessidade da relação intersubjetiva entre culturas distintas, e que o Direito deve, sim, "possibilitar essa conquista hermenêutica da reprodução cultural de universos vitais" (HABERMAS, 2004, p. 260). Em 
síntese, aos indivíduos, deve ser dada a chance de se seguir vivendo de acordo com a sua cultura de origem, inclusive repassando-a às próximas gerações, transformá-la, deixando de seguir os seus imperativos, ou mesmo romper totalmente com ela, de forma deliberada e consciente.

Sendo assim, percebe-se que as sociedades são formadas a partir de seus longos processos históricos, sendo estabelecidos, dentro delas, critérios éticos que acabam se refletindo nas interpretações sobre as regras de convivência. Todos os indivíduos estão interligados, mesmo que não percebam, e definem, intersubjetivamente, um horizonte de entendimento sobre em quais valores aquela sociedade se pauta.

Obviamente, no atual contexto pluralista, ocorre uma constante modificação da base formada pelos cidadãos, os quais dão o tom à democracia e participam dos processos de deliberação jurídica e política. Ocorrendo a alteração dessa base, muda também a forma como são vistos os direitos e princípios fundamentais então estabelecidos, os quais, entende Habermas, são importantes para a configuração de um patriotismo constitucional. Isso não significa, entretanto, que tais valores devem ser dominantes, esmagando a expressão das minorias. O que deve ocorrer é justamente o contrário: uma constante revisão do entendimento político e também jurídico, feito intersubjetivamente, envolvendo as maiorias e as minorias, com o objetivo de se promover inclusão social, pensamento o qual se encontra em concordância a teoria desconstrutivista apresentada e permite a tutela da dignidade da pessoa humana.

Nesse sentido, os indivíduos que chegam a um novo país devem ter o direito de lutar pelo reconhecimento de sua cultura, sem correr os riscos de sofrer uma aculturação, não devendo ser forçado a alterações na sua cultura, permitindo-se que, finalmente, possa-se obter novos entendimentos dentro da mesma sociedade, o que apenas se dá após longos anos. Inclusive, justamente pelo fato de não se poder coagir os imigrantes a abandonarem suas tradições, "também se amplia, de acordo com a nova forma de vida que se estabelece, o horizonte no qual os cidadãos interpretam os princípios constitucionais que têm em comum" (HABERMAS, 2004, p. 267). É diante dessas considerações que Estados que mudam sua base de cidadãos a partir de influxos migratórios devem estar mais atentos para perceber essas novas oscilações e a delicadeza dos temas dissonantes nas sociedades, que levam a movimentos de reconhecimento pela própria identidade dentro de uma cultura já definida.

\section{Conclusões}

Revista Publicum

Rio de Janeiro, v. 3, n. 1, 2017, p. 273-306.

http://www.e-publicacoes.uerj.br/index.php/publicum

DOI: 10.12957/publicum.2017.28999 
A onda de refugiados do Estado Islâmico já é, sem dúvidas, um dos maiores acontecimentos do século XXI. Trata-se de um novo contexto, que ainda não tem suas circunstâncias bem delimitadas e somente agora, após os primeiros compromissos entre os países europeus para recebimento dos refugiados, é que começam a ficar mais nítidas as responsabilidades que cada qual pode assumir para uma melhor solução aos envolvidos. Sabe-se, no entanto, a partir de uma breve análise da história, mais precisamente do contexto do início do século passado, que um tratamento humano que considere as singularidades individuais ao máximo possível não deve ser deixado de lado, se se deseja que o fracasso da histórica dos refugiados daquela outra época se repita.

Esforços devem ser empreendidos para o recebimento dos refugiados, que, no entanto, não devem ficar à margem da lei, evitando a criação de um verdadeiro "estado de exceção" paralelo a um Estado de direito democrático. As novas normas sobre imigração e refúgio que vierem a ser editadas nos países europeus devem promover uma política pública inclusiva, capaz de traçar não só as responsabilidades dos refugiados - as quais são plenamente aceitáveis, dentro da razoabilidade - mas também destes países e respectivas populações que os recebem. Não devem, portanto, deixar-se guiar por medidas políticas convenientes ou se submeter às pressões da população, preocupada com os direitos sociais, uma vez que argumentos desse tipo não condizem com uma ideia abrangente de justiça.

Os desafios continuarão ainda por anos, após o recebimento de mais refugiados, conforme planos de relocação desenvolvidos pelos países europeus, e envolverá a difícil tarefa de equilibrar uma sociedade pluralista, de forma que os novos cidadãos possam ter o direito a ter direitos e a bem viver. Mesmo porque, por mais que valores abstratos sejam definidos numa ordem internacional e sejam também tomados como norteadores das constituições nacionais, é sem dúvidas dentro das articulações da cultura que se pode concretizar os direitos individuais e uma realização pessoal. No entanto, apesar de todos os esforços empreendidos, deve-se reconhecer que tais articulações culturais nunca são perfeitas e acabadas, uma vez que incapazes de compreender e satisfazer todos os direitos de todos os indivíduos.

Nesse sentido, a própria ideia de justiça é variável, e só pode fazer sentido dentro de um contexto, relativos a determinadas circunstâncias. Assim, promover a justiça no caso dos refugiados é procurar satisfazer os direitos desses indivíduos, no maior número de casos possíveis e da melhor forma possível, o que significa dizer sem que se agrave situações ao redor, como dos próprios países e cidadãos que os recebem. Mas isso só se faz dentro de um paradigma em que se aceite a possibilidade de desconstruir algumas 
concepções, para que outras possam ser reconstruídas, de forma a retificar o pensamento anterior e poder melhor identificar as soluções justas. Dentre elas, imprescindível é a desconstrução do conceito moderno de nacionalidade, que não se aplica mais em sua totalidade, dentro de um mundo globalizado, e que apenas acaba por interferir de forma negativa na aceitação dos refugiados, visto que ignora a possibilidade de rever os valores que a sociedade entende que deve seguir e, inclusive, basear suas normas jurídicas.

É de se esperar, talvez, que a própria compreensão da quão bárbara é a invasão do Estado Islâmico sobre as terras desses refugiados possa contribuir para que os cidadãos dos países anfitriões atuem no sentido de se colocar no lugar do Outro, tentando falar a sua linguagem e compreender a sua cultura, sem o medo de, eventualmente, terem de mudar suas próprias concepções, o que favorece a tarefa da desconstrução. Somente assim poderá ser garantida também a defesa da dignidade humana desses indivíduos, de salutar importância hoje para as mais distintas sociedades, bem como para toda a sociedade global, que a ela se refere no plano jurídico internacional. Não se pode ainda olvidar que foram as atrocidades das guerras mundiais que levaram à percepção da necessidade de se permitir a dignidade de todos, como um esforço, ao lado de constantes diálogos, de serem minimizados os conflitos entre indivíduos e Estados, ao máximo possível.

Conclui-se, portanto, que a própria desconstrução da ideia clássica de nacionalidade e a defesa do princípio da dignidade da pessoa humana são pontos fundamentais para que se possa promover a justiça aos refugiados do Estado Islâmico. Primeiro, porque a nacionalidade já não se apresenta mais como o conceito rígido de indivíduos de uma origem comum, diante da existência de uma ordem normativa internacional e institucionalidade e de um mundo profundamente globalizado; segundo, porque já se viu na história das Guerras Mundiais ao que tal concepção pode levar. Nesse sentido, culturas e ideias diferentes devem ser possibilitadas de conviverem em conjunto, devendo as portas serem abertas para receber aqueles que não mais podem viver nas suas terras de origem, ainda que assim muito desejassem.

\section{Referências}

AGAMBEN, Giorgio. Estado de exceção. Trad. Iraci D. Poleti. 2. ed. São Paulo: Boitempo, 2004 (e-Book). 
ALEMANHA debate endurecer leis de asilo. Terra Notícias. 1 out. 2015. Disponível em: $<$ http://noticias.terra.com.br/alemanha-debate-endurecer-leis-deasilo,0b1d4721c4cdbf8285897224fa30eb3d8rkh2e3v.html>. Acesso em: 30 maio 2017.

ALEXY, Robert. Constitucionalismo discursivo. Porto Alegre: Livraria do Advogado, 2007.

ARENDT, Hannah. Origens do totalitarismo. Trad. Roberto Raposo. São Paulo: Companhia das Letras, 2012.

BALKIN, Jack M. Transcendental Deconstruction, Transcendent Justice. Originally Published at 92 Mich. L. Rev. 1131 (1994). Disponível em: <http://www.yale.edu/lawweb/jbalkin/articles/transdecon1.pdf>. Acesso em: 29 maio 2017.

BASTOS, Celso Ribeiro Bastos. Curso de Teoria do Estado e Ciência Política. 3. ed. São Paulo: Saraiva, 1995.

BONAVIDES, Paulo. Ciência Política. 10. ed. rev. atual. São Paulo: Malheiros, 2003.

CÂMARA dos EUA aprova projeto para dificultar entrada de refugiados sírios. G1 - Globo. 19 nov. 2015. Disponível em: <http://g1.globo.com/mundo/noticia/2015/11/camara-doseua-aprova-projeto-para-dificultar-entrada-de-refugiados-sirios.html>. Acesso em: 10. dez. 2015.

CAMARGO, Marcelo Novelino. Leitura complementares de direito constitucional. Salvador: Juspodivm, 2007.

COMPARATO, Fábio Konder. Ética: Direito, moral e religião no mundo moderno. São Paulo: Companhia das Letras, 2006.

CANOTILHO, J. J. Gomes. Direito Constitucional e Teoria da Constituição. 3. ed. Coimbra: Almedina, 1998.

DERRIDA, Jacques. A escritura e a diferença. Trad. Maria Beatriz Marques Nizza da Silva, Pedro Leite Lopes e Pérola de Carvalho. São Paulo: Perspectiva, 2014.

DIMOULIS, Dimitri; MARTINS, Leonardo. Teoria geral dos direitos fundamentais. São Paulo: Revista dos Tribunais, 2007.

FOTO chocante de menino morto vira símbolo da crise migratória europeia. G1 - Globo. 2 set. 2015. Disponível em: <http://g1.globo.com/mundo/noticia/2015/09/foto-chocantede-menino-morto-vira-simbolo-da-crise-migratoria-europeia.html>. Acesso em: 27 maio 2017.

GUIMARÃES, Aquiles Côrtes. Fenomenologia e direitos humanos. Rio de Janeiro: Lúmen Júris, 2007.

HABERMAS, Jürgen. A inclusão do outro - estudos de teoria política. Tradução de George Sperber, Paulo Asthor Soethe e Milton Camargo Mota. 2. ed. São Paulo: Loyola, 2004.

Sobre a Constituição da Europa: um ensaio. Tradução de Denilson Luis Werle, Luiz Repa e Rúrion Melo. São Paulo: Unesp, 2012. 
HOLANDA e França rejeitam constituição única. UOL. 2. jun. 2005. Disponível em: <http://vestibular.uol.com.br/resumo-das-disciplinas/atualidades/uniao-europeia-2holanda-e-franca-rejeitam-constituicao-unica.htm>. Acesso em: 27 maio 2017.

LA MARCHA de la vergüenza. El Mundo. 20 out. 2015. Disponível em: <http://www.elmundo.es/internacional/2015/10/20/56265d9d268e3e534d8b45d7.html> . Acesso em: 27 maio 2017.

MENINO é resgatado sob escombros de prédio após bombardeio na Síria. GI- Globo. 18 ago. 2016. Disponível em: <http://g1.globo.com/mundo/noticia/2016/08/menino-eresgatado-sob-escombros-de-predio-apos-bombardeio-na-siria.html>. Acesso em: 29 maio 2017.

MERKEL diz que chegada de refugiados mudará Alemanha. G1- Globo. 7 set. 2015. Disponível em: <http://g1.globo.com/mundo/noticia/2015/09/merkel-diz-que-chegadade-refugiados-mudara-alemanha.html>. Acesso em: 27 maio 2017.

NAÇÕES UNIDAS. Assembleia Geral. Declaração Universal dos Direitos Humanos. Disponível em: <http://www.direitoshumanos.usp.br/index.php/Declara\%C3\%A7\%C3\%A3o-Universaldos-Direitos-Humanos/declaracao-universal-dos-direitos-humanos.html.> Acesso em: 30 maio 2017.

NÚMERO de refugiados é o maior desde segunda guerra mundial. Revista Época. Disponível em: <http://epoca.globo.com/tempo/noticia/2015/09/numero-de-refugiadose-o-maior-desde-segunda-guerra-mundial.html>. Acesso em: 30 maio 2017.

ONU convova todos os países da EU a receber refugiados. Revista Veja. 4 set. 2015. Disponível em: <http://veja.abril.com.br/noticia/mundo/onu-convoca-todos-os-paises-daue-a-receber-refugiados/>. Acesso em: 30 maio 2017.

O QUE há por tras da crise de imigrantes na Europa. G1 - Globo. 29 ago. 2015. Disponível em: <http://g1.globo.com/mundo/noticia/2015/08/o-que-ha-por-tras-da-crise-deimigrantes-na-europa.html>. Acesso em: 27 maio 2017.

PECES-BARBA, Gregório Martínez. La dignidad de la persona desde la Filosofia del Derecho. Madrid: Dykinson, 2003.

PIOVESAN, Flávia. Direitos humanos e o direito constitucional internacional. 14. ed. rev. e atual. São Paulo: Saraiva, 2013.

REALE, Miguel. Fundamentos do direito. São Paulo: Revista dos Tribunais; Universidade de São Paulo, 1972.

. Teoria tridimensional do direito. São Paulo: Saraiva, 1994.

REFUGIADOS na Europa: a crise em mapas e gráficos. BBC Brasil. 6 set. 2015. Disponível em:

<http://www.bbc.com/portuguese/noticias/2015/09/150904_graficos_imigracao_europa _rm>. Acesso em: 27 maio 2017. 
REINO UNIDO. House of Commons. Migration crisis - Seventh Report of Session 2016-17. Relatório. Disponível em:

https://publications.parliament.uk/pa/cm201617/cmselect/cmhaff/24/24.pdf?utm_sourc e=24\&utm_medium=module\&utm_campaign=modulereports $>$. Acesso em: 18 jul. 2017.

SARLET, Ingo Wolfgang. Dignidade da Pessoa Humana e Direitos Fundamentais na Constituição Federal de 1988. Porto Alegre: Livraria do Advogado, 2001.

SEN, Amartya. A ideia de justiça. Trad. Denise Bottmann e Ricardo Doninelli Mendes. São Paulo: Companhia das Letras, 2011.

UNIÃO EUROPEIA. European Court of Human Rights. Case of Leyla Şahín v. Turkey (Application no. 44774/98). Disponível em: <http://hudoc.echr.coe.int/eng\#\{"fulltext":["niqab"],"languageisocode":["ENG"],"kpthesa urus":["269"], "documentcollectionid2":["GRANDCHAMBER","CHAMBER"],"itemid":["00170956"]\}>. Acesso em: 30 maio 2017.

European Court of Human Rights. Case of S.A.S. v. France (Application no. 43835/11). Disponível em: <http://hudoc.echr.coe.int/eng\#\{"fulltext":["niqab"],"languageisocode":["ENG"],"kpthesa urus":["269"],"documentcollectionid2":["GRANDCHAMBER","CHAMBER"],"itemid":["001145466"]\}>. Acesso em: 30 maio 2017.

UNIÃO Europeia aprova divisão de 120 mil refugiados entre países membros. Folha de São Paulo. 22 set. 2015.2 Disponível <http://www1.folha.uol.com.br/mundo/2015/09/1684893-uniao-europeia-aprova-

divisao-de-120-mil-refugiados-entre-paises-membros.shtml>. Acesso em: 30 maio 2017.

VERDÚ, Pablo Lucas. A luta pelo Estado de Direito. Tradução e prefácio de Agassiz Almeida Filho. Rio de

Janeiro: Forense, 2007.

Enviado em: 02/06/2017

Aprovado em: 05/08/2017 